\title{
Penyuluhan Kesehatan Cegah Stunting dengan Perbaikan Pola Makan, Pola Asuh Dan Sanitasi pada Ibu Hamil di UPT Puskesmas Antang
}

\author{
${ }^{1}$ Nour Sriyanah, ${ }^{2}$ Suradi Efendi, ${ }^{3}$ Nurmaulida, ${ }^{4}$ Zulfadhilah.D, ${ }^{5}$ Rahmawati \\ 1,2,3,4,5Prodi Ilmu Keperawatan, Sekolah Tinggi IImu Kesehatan Makassar \\ Korespondensi: nsnoursriyanah@gmail.com
}

\begin{abstract}
Abstrak: Stunting adalah masalah kurang gizi kronis yang disebabkan oleh kurangnya asupan gizi dalam waktu yang cukup lama, sehingga mengakibatkan gangguan pertumbuhan pada anak yakni tinggi badan anak lebih rendah atau pendek (kerdil) dari standar usianya. Kondisi tubuh anak yang pendek seringkali dikatakan sebagai faktor keturunan (genetik) dari kedua orang tuanya, sehingga masyarakat banyak yang hanya menerima tanpa berbuat apa-apa untuk mencegahnya. Padahal seperti kita ketahui, genetika merupakan faktor determinan kesehatan yang paling kecil pengaruhnya bila dibandingkan dengan faktor perilaku, lingkungan (sosial, ekonomi, budaya, politik), dan pelayanan kesehatan. Dengan kata lain, stunting merupakan masalah yang sebenarnya bisa dicegah. Stunting menjadi masalah gagal tumbuh yang dialami oleh oleh bayi dibawah 5 tahun yang mengalami kurang gizi semenjak didalam kandungan hingga awal bayi lahir. Penilaian status gizi stunting dapat dilakukan melalui pengukuran antropometri TB/U diklasifikasikan melalui status klasifikasi gizi. Stunting adalah kondisi tinggi badan anak lebih pendek dibanding tinggi badan anak seusianya. Menurut UNICEF, stunting terjadi pada anak-anak usia 0 sampai 59 bulan dengan tinggi di bawah minus (stunting sedang dan berat) dan minus tiga (stunting kronis) diukur dari standar pertumbuhan anak keluaran WHO. Di Indonesia, kasus stunting masih menjadi masalah kesehatan dengan jumlah yang cukup banyak. Bedasarkan Riset Kesehatan Dasar tahun 2013, sekitar 37,2 persen anak Indonesia di bawah usia 5 tahun mengalami stunting.
\end{abstract}

Kata Kunci: ASI Eksklusif, Stunting, Ibu hamil

\begin{abstract}
Stunting is a chronic malnutrition problem caused by lack of nutritional intake for a long time, resulting in growth disorders in children, namely the child's height is lower or shorter (short) than the standard age. The condition of a child's short body is often said to be a hereditary factor (genetic) from both parents, so that many people just accept it without doing anything to prevent it. In fact, as we all know, genetics is a determinant of health that has the least effect when compared to behavioral, environmental (social, economic, cultural, political) factors and health services. In other words, stunting is a preventable problem. Stunting is a growth failure problem experienced by infants under 5 years of age who are malnourished since in the womb until the baby is born. Assessment of stunting nutritional status can be done through anthropometric measurements of TB/U classified through nutritional classification status. Stunting is a condition where the child's height is shorter than the height of children his age. According to UNICEF, stunting occurs in children aged 0 to 59 months with a height below minus (moderate and severe stunting) and minus three (chronic stunting) measured from the WHO child growth standards. In Indonesia, stunting is still a health problem in quite a large number. Based on the 2013 Basic Health Research, around 37.2 percent of Indonesian children under the age of 5 are stunted. Kata Kunci: Exclusive Breastfeeding, Stunting, Pregnant.
\end{abstract}

\section{PENDAHULUAN}

Stunting merupakan gangguan pertumbuhan dan perkembangan yang dialami oleh Anakanak akibat gizi buruk infeksi berulang dan dampak psikososial yang tidak mendukung ${ }^{1}$. Kekurangan gizi yang dialami oleh Anak dapat menyebabkan stunting. Kejadian ini paling sering terjadi di Negara dengan penghasilan rendah. World Health Organization (WHO) bahkan mencatat bahwa ada sekitar 156,8 Juta terkena dampak stunting pada tahun $2015^{2}$. Salah satu Negara dengan prevalensi stunting yang tinggi khususnya Anak dibawah 5 tahun yakni Madagaskar. Angka stunting di Negara ini tertinggi padaTahun 2009, hasil penelitian menemukan bahwa faktor gizi yang paling berkontribusi pada kejadian stunting di Negara ini ${ }^{3}$. Penelitian Beat juga menemukan bahwa penyebab stunting ini di Negara Indonesia adalah kurangnya pendidikan Ibu, Sistem pertanian dan pangan, air, sanitasi dan lingkungan ${ }^{4}$.

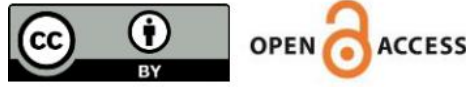

(c) Idea PengabdianMasyarakat (2021) 
Pendidikan dan pengetahuan Ibu mengenai stunting sangatlah berkontribusi sehingga perlu diadakan pendidikan kesehatan maupun penyuluhan ${ }^{5}$. Penyuluhan dalam bentuk pemahaman masyarakat misalnya mengenai Gizi makanan harus dilakukan secara berkelanjutan dan dominan ${ }^{6}$.

\section{METODE}

Metode pengabdian Masyarakat ini dengan metode penyuluhan, diskusi dan Tanya jawab kepada Ibu hamil dan ibu yang membawa balita di Puskesmas Antang Kota Makassar, berikut kami lampirkan agenda kegiatan pengabdian.

Tabel 1 : Planning of Action (POA)

\begin{tabular}{|c|c|c|c|}
\hline No & Waktu & Kegiatan Penyuluhan & Kegiatan Peserta \\
\hline 1. & 5 menit & $\begin{array}{l}\text { Pembukaan: } \\
\text { 1. Memberi salam } \\
\text { 2. Menjelaskan tujuan pembelajaran. } \\
\text { 3. Menyebutkan materi / pokok } \\
\text { bahasan yang akan disampaikan }\end{array}$ & $\begin{array}{l}\text { 1. Menjawab salam } \\
\text { 2. Mendengarkan dan } \\
\text { memperhatikan }\end{array}$ \\
\hline 2 & 35 menit & $\begin{array}{l}\text { Pelaksanaan : } \\
\text { Menjelaskan materi penyuluhan } \\
\text { secara berurutan dan teratur. } \\
\text { Materi : } \\
\text { 1. pengertian stunting } \\
\text { 2. Pencegahan stunting sejak dini }\end{array}$ & Menyimak, memperhatikan \\
\hline 3. & 20 menit & $\begin{array}{l}\text { Evaluasi : } \\
\text { Meminta kepada warga menjelaskan } \\
\text { atau menyebutkan kembali tentang: } \\
\text { 1. apa aitu stunting } \\
\text { 2. Pencegahan sejak dini }\end{array}$ & $\begin{array}{l}\text { Bertanya dan menjawab } \\
\text { pertanyaan. }\end{array}$ \\
\hline 4. & 5 menit & $\begin{array}{l}\text { Penutup : } \\
\text { 1. Mengucapkan terimakasih atas } \\
\text { peran peserta } \\
\text { 2. Mengucapkan terima kasih dan } \\
\text { mengucapkan salam. }\end{array}$ & Menjawab salam \\
\hline
\end{tabular}

\section{Kriteria Evaluasi}

\section{Evaluasi struktur}

1. Ibu hamil dan ibuu yang membawa bayi dan balita ikut dalam penyuluhan pencegahan stunting

2. Penyelenggaraan penyuluhan dilakukan di Puskesmas Antang Kota Makassar

3. Pengorganisasian penyuluhan dilakukan 2 hari sebelumnya

This is an open-access article under the CC BY 4.0 International 


\section{Evaluasi proses}

1. Ibu hamil dan ibu yang membawa bayi an balita antusias terhadap materi penyuluhan

2. Ibu hamil dan ibu yang membawa bayi daan balita tidak meninggalkan tempat sebelum kegiatan selesai

3. Ibu hamil dan ibu yang membawa bayi daan balita terlibat aktif dalam kegiatan penyuluhan.

\section{Evaluasi hasil}

1. Ibu hamil dan ibu yang membawa bayi dan balita dapat mengetahui dengan baik tentang apa saja penyebab anak stunting

2. Ibu hamil dan ibu yang membawa bayi dan balita dapat mengetahui tentang pencegahan stunting

\section{HASIL DAN PEMBAHASAN}

\section{Tahap Persiapan}

Persiapan dilakukan dengan menyampaikan kepada mitra apa yang akan dilakukan, kemudian Tim melakukan Pembuatan Satuan Acara Penyuluhan (SAP), serta me nyiapkan bahan dan alat yang akan digunakan misalnya Poster dan Leaflet.

\section{Tahap Pelaksanaan}

Kami datang ke Puskesmas Antang Kota Makassar untuk melakukan persiapan, menata tempat yang akan digunakan. Para kader berkumpul di tempat yang diarahkan oleh para anggota dan mahasiswa.. Kegiatan diawali dengan rekan saya selaku moderator (nurul safitri, amd kep) membuka acara kegiatan penyuluhan. Saya selaku penyaji menyampaikan materi penyuluhan ( nur maulidah, amd kep). selaku fasilitator (ibu KTU Dan Kepala Pkm Antang Kota Makassar ) dan dibantu Tim kelompok 3
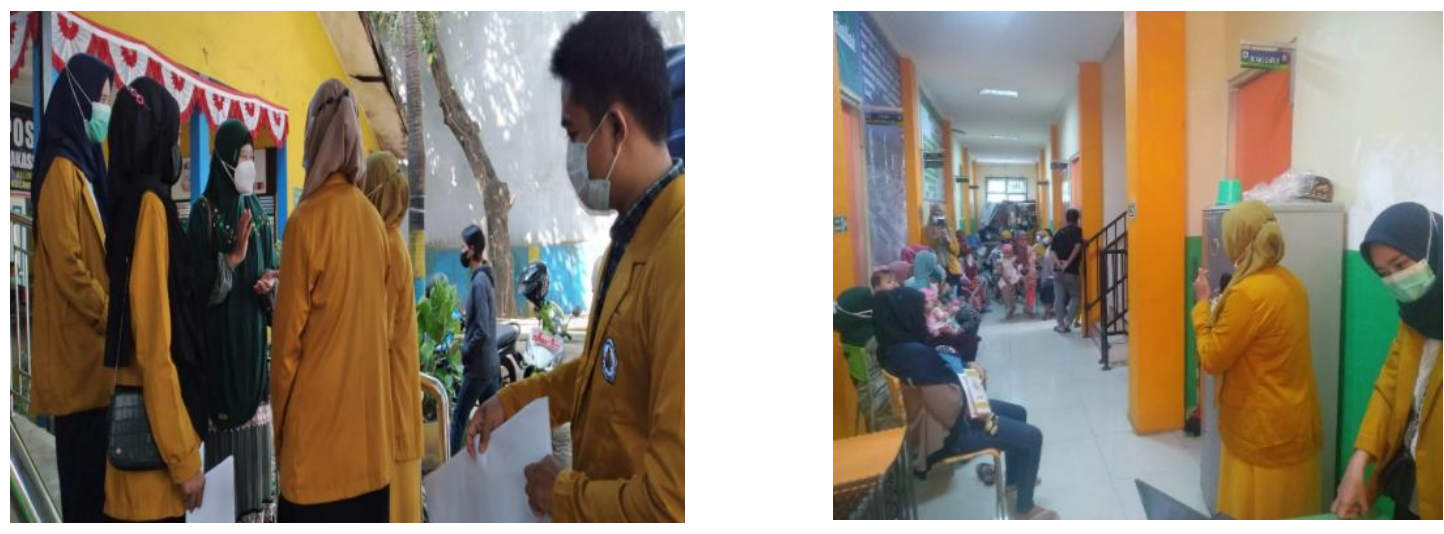

Gambar 1 dan 2 : Pelaksanaan Kegaiatan Pengabdian Masyarakat

Pelaksanaan edukasi dan penyuluhan kepada Masyarakat sangat penting dan bermanfaat untuk meningkatkan pengetahuan mereka, penelitian di Kota Pontianak mengemukakan hasil bahwa penyuluhan dengan media Video sangat efektif, ini terbukti dengan adanya peningkatan pengetahuan sebelum dan sesudah penyuluhan ${ }^{7}$. Peran kader dan Bidan untuk memberikan edukasi ke Ibu Bayi 
terbukti akan memacu motivasinya dalam memberikan asupan gizi sesuai kebutuhan Bayi sehingga terhindar resiko stunting ${ }^{8}$. Upaya preventif dalam mencegah stunting sebaiknya dilakukan sejak dini, bahkan sejak persiapan pra nikah sehingga calon orang tua lebih memahami pentingnya Nutrisi dan Gizi yang seimbang untuk perkambangan Bayi ${ }^{9}$.

Di jember misalnya, salah satu program kader Posyandu dengan memanfaatkan penyuluhan serta penanaman hidroponik sebagai lahan untuk budidaya sayur sehingga Masyarakat dapat memanfaatkan tanaman tersebut sebagai ketahanan pangan dan upaya penanggulangan stunting ${ }^{10}$.

\section{KESIMPULAN}

Pengabdian Masyarakat ini berkesimpulan bahwa penyeluhan harus dilakukan secara terus menerus untuk menambah pengetahuan masyarakat dan kader Puskesmas sehingga mereka sadar akan pentingnya makanan bergizi untuk mencegah stunting pada Bayi dan Anak. Selain itu pola Asuh orang tua juga berperan penting dalam pencegahan stunting.

Sanitasi dan dampak lingkungan tempat tinggal harus bersih dan harus terhindar dari keadaan kumuh yang memicu perkembangan bakteri yang bisa menkontaminasi anak saat berada disekitar Rumah.

Pencegahan stunting bukan hanya menjadi tanggung jawab Ibu dan Ayah tetapi semua pihak termasuk Pemerintah yang meluncurkan program-program pemenuhan gizi anak dan orang tua.

\section{UCAPAN TERIMAKASIH}

Kami sampaikan ucapan terimakasih kepada Dinas Kesehatan Kota Makassar, terkhusus Puskesmas Antang, Mahasiswa dan semua pihak yang telah berkontribusi dalam kegiatan ini.

\section{DAFTAR PUSTAKA}

1. WHO. Stunting in a nutshell [Internet]. World Health Organization. 2015 [cited 2021 Oct 9]. Available from: https://www.who.int/news/item/19-11-2015-stunting-in-a-nutshell

2. WHO. Global and regional trends by WHO Regions, 1990-2014 Stunting [Internet]. World Health Organization. 2015 [cited 2021 Oct 9]. Available from: http://apps.who.int/gho/data/node.main.NUTWHOREGIONS?lang=en

3. Rakotomanana H, Gates GE, Hildebrand D, Stoecker BJ. Determinants of stunting in children under 5 years in Madagascar. Matern Child Nutr. 2017;13(4).

4. Beal T, Tumilowicz A, Sutrisna A, Izwardy D, Neufeld LM. A review of child stunting determinants in Indonesia. Matern Child Nutr. 2018;14(4):1-10.

5. Puspitasari A, Putra WD, Amir H. Pencegahan Stunting Pada Anak Di Desa Tamangapa Kec. Ma'rang Kab. Pangkep. Idea Pengabdi Masy. 2021;1(1):05-8.

6. Arsyati AM. Pengaruh Penyuluhan Media Audiovisual Dalam Pengetahuan Pencegahan Stunting Pada Ibu Hamil Di Desa Cibatok 2 Cibungbulang. Promotor. 2019;2(3):182.

7. Septianingsih N, Pangestu JF. Volume 6 Nomor 1 Januari 2020 , hlm 7 - 15 P - ISSN 2460 - 1853 Pervedaan Pengetahuan Ibu Balita sebelum dan Sesudah duberikan Penyuluhan tentang Stuntung melalui Media Video dan Leaflet di Wilayah Kerja Puskesmas Saigon Kecamatan Pontianak Timur, Jurnal Kebidana Khatulistiwa, Volume 6 Nomor 1 Januari 2020 , hlm 7 - 15 P ISSN 2460 - 1853. 2020;6.

This is an open-access article under the CC BY 4.0 International

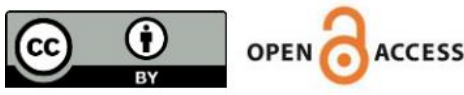


8. Wulandari HW, Kusumastuti I. Pengaruh Peran Bidan, Peran Kader, Dukungan Keluarga dan Motivasi Ibu terhadap Perilaku Ibu dalam Pencegahan Stunting pada Balitanya. J Ilm Kesehat. 2020;19(02):73-80.

9. Fauziatin N, Kartini A, Nugraheni S, Promosi-Kesehatan M, Masyarakat F-K, Kesehatan-Masyarakat F. Pengaruh Pendidikan Kesehatan dengan Media Lembar Balik Tentang Pencegahan Stunting Pada Calon Pengantin. VISIKES J Kesehat Masy [Internet]. 2019;18(2):224-33. Available from: http://publikasi.dinus.ac.id/index.php/visikes

10. Norcahyanti I, Pratama ANW, Pratoko DK. Upaya Pencegahan Stunting dengan Optimalisasi Peran Posyandu Melalui Program Kemitraan Masyarakat. Dedication J Pengabdi Masy. 2019;3(2):73-80. 